\title{
Echocardiography in the evaluation of athletes [version 1;
}

\section{peer review: 2 approved, 1 approved with reservations]}

\author{
Gonzalo Grazioli*, Maria Sanz*, Silvia Montserrat, Bàrbara Vidal, Marta Sitges
}

Cardiology Department, Hospital Clínic, Universitat de Barcelona, IDIBAPS, Institut d'Investigacions Biomèdiques August Pi iSunyer, Barcelona, Catalonia, Spain

${ }^{*}$ Equal contributors

\author{
V1 First published: 15 Jun 2015, 4:151 \\ https://doi.org/10.12688/f1000research.6595.1 \\ Latest published: 15 Jun 2015, 4:151 \\ https://doi.org/10.12688/f1000research.6595.1
}

\section{Abstract}

Echocardiography is currently a widely available imaging technique that can provide useful data in the field of sports cardiology particularly in two areas: pre-participation screening and analysis of the cardiac adaptation induced by exercise.

The application of pre-participation screening and especially, the type and number of used diagnostic tests remains controversial.

Echocardiography has shown though, higher sensitivity and specificity as compared to the ECG, following a protocol adapted to athletes focused on ruling out the causes of sudden death and the most common disorders in this population. It is still a subject of controversy the actual cost of adding it, but depending on the type of sport, echocardiography might be cost-effective if added in the first line of examination.

Regarding the evaluation of cardiac adaptation to training in athletes, echocardiography has proved to be useful in the differential diagnosis of diseases that can cause sudden death, analysing both the left ventricle (hypertrophy cardiomyopathy, dilated cardiomyopathy, left ventricle non compaction) and the right ventricle (arrhythmogenic right ventricular cardiomyopathy).

The aim of this paper is to review the current knowledge and the clinical practical implications of it on the field of echocardiography when applied in sport cardiology areas.

\section{Keywords}

echocardiography, athletes, pre-participation screening , athlete's heart

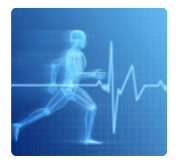

This article is included in the Sports cardiology

collection.

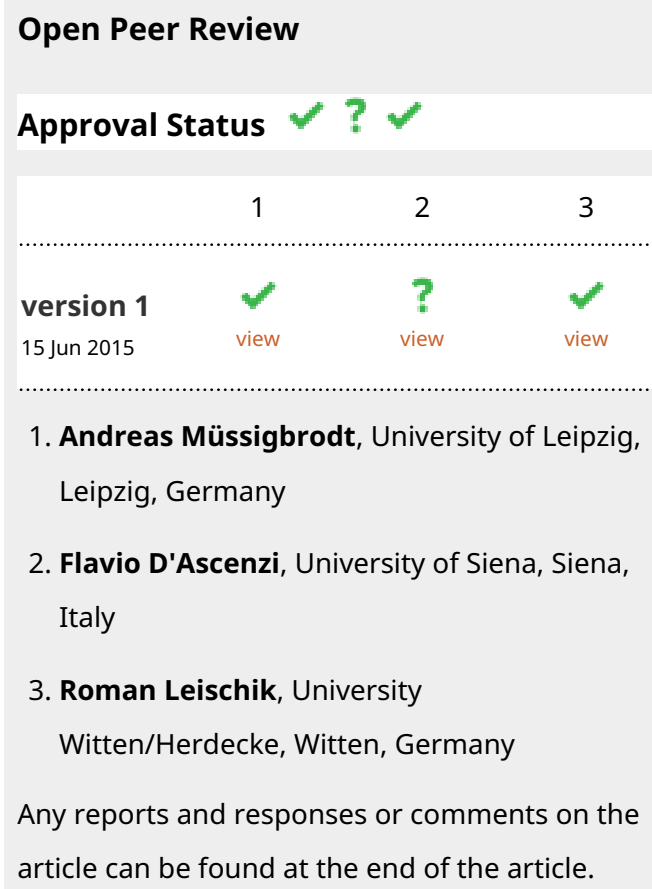

1. Andreas Müssigbrodt, University of Leipzig, Leipzig, Germany

2. Flavio D'Ascenzi, University of Siena, Siena, Italy

\section{Roman Leischik, University}

Witten/Herdecke, Witten, Germany

Any reports and responses or comments on the article can be found at the end of the article. 
Corresponding author: Marta Sitges (msitges@clinic.ub.es)

Competing interests: No competing interests were disclosed.

Grant information: This work was partially funded by grants from Generalitat de Catalunya (FI-AGAUR 2014-2017 (RH 040991, M. Sanz) and Consell Catala de l'Esport 11/2014, and from the Spanish Government (Plan Nacional I+D+i, Ministerio de Innovación y Ciencia DEP 2010-20565, Intensificación Actividad Investigadora, Instituto de Salud Carlos III (M Sitges), Plan Nacional I+D, Ministerio de Economia y Competitividad DEP2013-44923-P).

Copyright: (c) 2015 Grazioli G et al. This is an open access article distributed under the terms of the Creative Commons Attribution License, which permits unrestricted use, distribution, and reproduction in any medium, provided the original work is properly cited. Data associated with the article are available under the terms of the Creative Commons Zero "No rights reserved" data waiver (CC0 1.0 Public domain dedication).

How to cite this article: Grazioli G, Sanz M, Montserrat S et al. Echocardiography in the evaluation of athletes [version 1; peer review: 2 approved, 1 approved with reservations] F1000Research 2015, 4:151 https://doi.org/10.12688/f1000research.6595.1

First published: 15 Jun 2015, 4:151 https://doi.org/10.12688/f1000research.6595.1 


\section{Contributions of echocardiography in athletes}

The number of people practicing sport has increased about five fold over the past 30 years ${ }^{1}$. The benefits of sport practice in improving cardiovascular health are unquestionable ${ }^{2}$, but an increase in cardiovascular events has also been demonstrated during its practice ${ }^{3}$. As a consequence, the absolute number of people at risk of sudden cardiac death (SCD) during exercise is also increasing ${ }^{4}$. Sports activity is not a cause of the increased mortality per se; rather, it might act as a trigger of cardiac arrest in athletes with structural or electrical heart abnormalities that generating malignant arrhythmias. Thus, it seems reasonable that every effort should be made for early recognition of any disease that may put the athlete at risk, keeping in mind the perspective that inadequate disqualification of individuals might also pose a risk.

Therefore, a pre-participation screening (PPS) protocol seems to be of interest. Consequently, the European Society of Cardiology ${ }^{5}$ has proposed an exam which emphasizes three points or steps: a) family and personal history, b) physical examination and c) 12-lead electrocardiogram (ECG). The ECG has demonstrated a $70 \%$ sensitivity to detect the most frequent causes of SCD in young athletes ${ }^{6,7}$. However, about a third of these athletes with an anomalous origin of coronary arteries, aortic diseases and incipient forms of cardiomyopathies will present with a normal ECG.

The echocardiogram might be a useful, non-invasive and accessible tool to increase sensitivity of screening ${ }^{8}$. Our group reported the echocardiographic findings among 2688 competitive athletes; most of the echocardiographic evaluations were normal and only 203 (7.5\%) showed abnormalities ${ }^{9}$. Cessation of athletic activity was indicated in 4 athletes: 2 for hypertrophic cardiomyopathy (electrocardiography had shown changes that did not meet diagnostic criteria), 1 pectus excavatum with compression of the right ventricle, and 1 significant pulmonary valve stenosis; the other minor alterations in echocardiography ( $7.5 \%$ of the total population) did not entail cessation of athletic activity and only indicated periodic monitoring.

Although rare, some cardiac structural changes can be missed on physical examination and electrocardiography; in contrast, they are easily recognized with echocardiography. These findings suggest the use of echocardiography in at least the first PPS of competitive athletes to improve the effectiveness of programs aimed at preventing SCD in athletes.

Currently, there is no consensus on what kind of echo scan has to be included in the PPS in order to detect the most prevalent cardiac abnormalities related to SCD. Some studies have suggested a quick 5 minute echocardiogram protocol ${ }^{10}$ while other studies have proposed longer protocols performing a complete echocardiogram ${ }^{11}$. In our group, we carry out the standard transthoracic echocardiographic views suggested by the European Society of Echocardiography ${ }^{12}$; we consider that the long-axis parasternal, the short-axis parasternal, the apical 4-chamber views and 2-chamber views, suprasternal and parasternal right view provide a high sensitivity to diagnose the most prevalent causes of SCD (summarized in Table 1).

Table 1. Echocardiographic scan protocol.

\begin{tabular}{|c|c|}
\hline View & Focus in ... \\
\hline $\begin{array}{l}\text { LV Parasternal long-axis view } \\
(2 \mathrm{D}+\mathrm{M} \text {-mode + colour Doppler })\end{array}$ & $\begin{array}{l}\text { - LV hypertrophy or dilatation } \\
\text { - Aortic and Mitral morphology and function } \\
\text { - Aortic root (Marfan) } \\
\text { - Ascending aorta (Marfan) }\end{array}$ \\
\hline $\begin{array}{l}\text { Parasternal short-axis view at } \\
\text { aortic valve level } \\
(2 D+\text { colour Doppler })\end{array}$ & $\begin{array}{l}\text { - Coronary artery origin } \\
\text { - Aortic valve morphology } \\
\text { - Pulmonary valve } \\
\text { - Atrial septum } \\
\text { - Ventricular septum } \\
\text { - Persistent Ductus } \\
\text { - LV hypertrophy } \\
\text { - LV non-compaction }\end{array}$ \\
\hline Parasternal right view & - RV morphology and function \\
\hline $\begin{array}{l}\text { Apical 4-chamber view } \\
(2 D+\text { colour Doppler }+C W \\
\text { aortic) }\end{array}$ & $\begin{array}{l}\text { - LV function } \\
\text { - RV morphology and function } \\
\text { - Aortic, mitral, and tricuspid valves morphology and function } \\
\text { - Atrial and ventricular septum } \\
\text { - Pulmonary veins }\end{array}$ \\
\hline Suprasternal view & $\begin{array}{l}\text { - Aortic arch } \\
\text { - Arterial Ductus }\end{array}$ \\
\hline Subcostal view & $\begin{array}{l}\text { - RV morphology and function } \\
\text { - Atrial septum } \\
\text { - Ventricular septum }\end{array}$ \\
\hline
\end{tabular}


The most common abnormalities detected in athlete's echocardiograms can be divided into two different groups: physiological structural and functional cardiac adaptive changes that result in what is called the athlete's heart, and echocardiographic signs of different cardiomyopathies that can induce SCD (Table 2).

\section{Table 2. Echocardiographic findings in athletes.}

\begin{tabular}{|c|c|}
\hline Athlete's Heart & $\begin{array}{l}\text { - Ventricular dilatation and hypertrophy } \\
\text { - Atrial dilatation } \\
\text { - Ventricular hypertrabeculation } \\
\text { - Mild aortic dilatation }\end{array}$ \\
\hline $\begin{array}{l}\text { Sudden Cardiac } \\
\text { Death }\end{array}$ & $\begin{array}{l}\text { Most common: } \\
\text { - Hypertrophic cardiomyopathy } \\
\text { - Anomalous origin of coronary artery } \\
\text { Less common: } \\
\text { - Aortic dilatation (Marfan) } \\
\text { - Myocarditis } \\
\text { - Mitral valve prolapse } \\
\text { Uncommon: } \\
\text { - Arrhytmogenic RV cardiomiopathy } \\
\text { - Atherosclerotic coronary artery diseases } \\
\text { - Aortic valve stenosis }\end{array}$ \\
\hline
\end{tabular}

Hypertrophic cardiomyopathy constitutes the leading cause of SCD in young athletes ${ }^{13}$. The ECG has demonstrated a high sensitivity in the diagnosis of this entity, but there is still around $10 \%$ of patients with hypertrophic cardiomyopathy, who have abnormal ECGs ${ }^{14-16}$. On the other hand, $9 \%$ of the athletes with mild adaptive left ventricular (LV) hypertrophy show pathological changes in the ECG ${ }^{17}$. In both situations an echo scan would help to achieve the correct diagnosis.

The anomalous origin of the coronary arteries was considered to be a rare cause of SCD in athletes, but nowadays it has been demonstrated that it can be related to up to half of the previously asymptomatic SCD cases ${ }^{15}$. It was the second cause of sudden death associated with sports in the largest register of SCD in athletes ${ }^{13}$. The resting ECG of these athletes is normal, so this entity, if asymptomatic, cannot be detected in a regular PPS based on anamnesis, physical examination and ECG. It is known that an echocardiogram performed by physicians with adequate training can differentiate coronary anomalies with high sensitivity ${ }^{18}$, and therefore echo is again a key tool to unmask these asymptomatic patients.

Aortic root diseases are an infrequent cause of SCD in young people ${ }^{17}$, although they seem to be a more prevalent cause of SCD in athletes ${ }^{19}$. Echocardiogram allows for the diagnosis as well as the follow up of these patients. Similarly, bicuspid aortic valve without significant functional abnormalities would not be diagnosed in a regular PPS, and again, the echocardiogram would allow for an early diagnosis and a proper follow up ${ }^{20}$.

Finally, an echo scan is recommended in congenital heart disease patients, with special focus on ventricular morphology and function, pulmonary pressure and aortic diameters before starting an exercise protocol ${ }^{21}$.

\section{Usefulness of echocardiography in pre-participation screening}

To evaluate the cost effectiveness of the addition of a complementary study to the standard PPS, we have to take into account three basic parameters: a) incidence of SCD related to sport practice in the population b) cost of the study; c) years of potential life saved.

To date, there is no consensus which is the real incidence of SCD related to sports practice, because it depends on the analyzed population. Studies in Italy ${ }^{22}$ and Israel ${ }^{23}$ have reported an incidence of 2 cases of sudden death per 100,000 athletes per year, while other studies in France have documented an incidence of $<1$ per 100,000 athletes ${ }^{4}$. On the other hand, the cost to perform an echocardiography is significantly different between American countries ${ }^{7}$ and Europe $^{24}$. Finally, the quantification of the years of potential life lost depends on which population is considered, from school age ${ }^{25}$ or all young adults up to master athletes engaged in sports ${ }^{26}$. The weight of each of these three factors (incidence of SCD, cost of studies, years of life saved) in a given population to determine the cost-effectiveness of adding echocardiography in PPS represent the challenge that we will have to face in the upcoming years.

Currently, it is still controversial if the inclusion of an ECG in the regular PPS is cost effective ${ }^{27}$ in the USA, while in Europe this recommendation was established more than 10 years ago $^{5}$ and it has been adopted by the different sport committees ${ }^{28}$ and international federations ${ }^{29}$. Several studies have demonstrated the costeffectiveness of including an ECG in the PPS ${ }^{7,30}$, but to date, only a small population study in school-aged athletes has analyzed the cost-effectiveness of adding an echocardiography in the screening ${ }^{31}$; the study showed that adding echocardiography increased both the cost and the sensitivity. In our opinion, the echocardiography provides a higher sensitivity of the PPS, especially in some special populations with greater amount of cardiac disorders described such as competitive athletes ${ }^{9}$, sports with high static component ${ }^{32}$ or long distance endurance athletes ${ }^{33}$. Recommendations for PPS and use of echocardiography used by our group according to the level of sport practice and training are summarized in Table 3.

\section{Differentiating physiologic adaptation from pathology}

The structural and functional adaptive changes that the heart develops in response to exercise, classically called "athlete's heart", has intrigued clinicians and scientists for more than a century. In the $19^{\text {th }}$ century, Henschen described for the first time sport induced cardiac enlargement by auscultation and percussion ${ }^{34}$. Seventy years after the first athlete's electrocardiographic features were described $^{35,36}$ and a few years after the first 2-dimensional echocardiography images showed the characteristic chamber enlargement and myocardial hypertrophy of the athlete's heart. Finally, the current advanced echocardiography techniques and magnetic resonance imaging (MRI) have begun to clarify the mechanism involved in these athlete's heart adaptive features. The study of the athlete's heart is thus essential, not only to understand how cardiac adaptation contributes to improved athletic performance, but also to differentiate the athlete's heart from important disease states which may share similar morphologic features. We briefly review the physiologic and morphologic features associated with athletic training and the keys to differentiate normal adaptive athlete's heart 
Table 3. Cardiovascular pre-screening protocols according to the level of sport practice ${ }^{32}$. F\&P: family and personal, PE: physical exam.

\begin{tabular}{|l|l|l|l|}
\hline & History F\&P + PE & ECG & Echocardiography \\
\hline Recreational sports & Yes & Yes & No \\
\hline $\begin{array}{l}\text { Competitive athletes, High static and dynamic } \\
\text { component Endurance training, }>10 \text { hours/week }\end{array}$ & Yes & Yes & Yes \\
\hline
\end{tabular}

features from mild or initial expression forms of cardiac diseases such as hypertrophy cardiomyopathy (HCM), dilated cardiomyopathy (DCM), left ventricle non compaction (LVNC) and arrhythmogenic right ventricular cardiomyopathy (ARVC).

\section{Factors influencing cardiac remodeling in athletes}

Different forms of exercise impose different loads on the cardiovascular system. Classically, two forms have been described according to their hemodynamic effect. Endurance exercise results in an increased cardiac output due to the rise in heart rate and stroke volume, reduced peripheral resistance and moderate increment in systemic blood pressure, leading to a volume overload. On the other hand, strength exercise is characterized by a maintained or a slightly increased cardiac output and peripheral vascular resistance, which results in increased blood pressure and thus an increased LV afterload. Cycling or running are examples of endurance exercise while weightlifting is an example of strength exercise, but there are also overlapped sports combining endurance and strength hemodynamic conditions in different proportions such as soccer or hockey. These different hemodynamic conditions will result in different cardiac adaptive structural and functional changes. Moreover, cardiac remodeling is not a continuous response to exercise; it is influenced by individual genetic factors, gender and race. Thus, a proper athlete's evaluation should be individual and take into account these potential influencers.

\section{The left ventricle}

Endurance exercise LV remodeling is typically described as LV chamber enlargement with increased wall thickness resulting in an eccentric LV hypertrophy, while strength remodeling is described as a thickening of the LV wall with a slight increase in the size of the LV cavity resulting in a concentric hypertrophy. This dichotomous view, first described by Morganroth et al. ${ }^{37}$ is currently controversial. A meta-analysis by Pluim et al. ${ }^{38}$ initially confirmed this model; in contrast, a recent meta-analysis by Utomi et al. ${ }^{33}$ did not find this classic concentric remodeling in strength athletes and only found a slight LV dilatation and similar LV wall thickness as in endurance athletes. An increase in LV wall thickness is a typical feature of the athlete's heart, however it is usually minimal and within normal range. In a cohort of 947 elite athletes Pelliccia et al. ${ }^{39}$ found a LV wall thickness $>$ than $13 \mathrm{~mm}$ in only $1.7 \%$ of the athletes. Sharma et al. $^{40}$ in a cohort of 720 elite athletes also reported a low incidence with only $0.4 \%$ of subjects showing LV wall thickness $>12 \mathrm{~mm}$ among elite junior athletes. However, this small number of extreme cases of exercise-induced remodeling may be difficult to differentiate from mild forms of hypertrophic cardiomyopathy. Various studies have tried to find out the key to differentiate these two entities, but to date there is no pathognomonic sign available, and a combination of clinical and family history, electrocardiographic and echocardiographic features is recommended. The increase in $\mathrm{LV}$ wall thickness in athletes is an adaptation to increase stroke volume so it has to be accompanied by chamber enlargement. Thus, a $\mathrm{LV}$ end-diastolic diameter $>54 \mathrm{~mm}^{41}$, an increased LV volume and particularly LV volume/mass ratios by $\mathrm{MRI}^{42}$ have been proposed to differentiate athlete's heart from disease ${ }^{41}$.

Recent advances in echocardiographic techniques including Tissue Doppler Imaging (TDI) and Speckle Tracking Imaging (STI) permit an accurate assessment of the myocardial function, helping us to differentiate adaptation from disease. Numerous studies have demonstrated normal or even supranormal diastolic LV function in athletes $^{43}$; instead, the pathological forms of LV hypertrophy are typically associated with an impaired diastolic dysfunction characterized by lower early diastolic mitral annulus velocity ${ }^{44}$. Thus, the evaluation of diastolic LV function by TDI is nowadays mandatory in the evaluation of LV hypertrophy ${ }^{16}$. Figure 1 illustrates this echocardiographic differential diagnosis. In cases where differential diagnosis is unclear, MRI is useful. MRI offers a more accurate assessment of LV wall thickness, cardiac volumes, and tissue composition. Furthermore, adding gadolinium for late enhancement, the presence and location of myocardial fibrosis can be determined.

As previously described, LV cavity enlargement is part of the cardiac remodeling observed in response to exercise, but this LV dilatation is in most cases minimal and indexed LV cavity dimensions are below pathologic limits. However, in the selected population of endurance elite-athletes this LV remodeling can be extreme. In a study by Pelliccia et $a l .{ }^{45}$ more than $10 \%$ of elite ultra-endurance athletes had LV cavity end-diastolic dimensions $>60 \mathrm{~mm}$, simulating forms of DCM. LV systolic function is described to be in a normal range among athletes ${ }^{46}$, but again, studies including high intensity endurance athletes have revealed a slight LV systolic dysfunction with LV ejection fraction around $45-49 \%{ }^{47}$. In these extreme cases, the new advanced echocardiographic techniques can also help us. Although slightly lower ejection fraction of the LV might be found, the adaptive cardiac remodeling shows normal or even supranormal values of strain and strain rate by TDI, and normal values of longitudinal strain assessed by $\mathrm{STI}^{48}$. In contrast, in DCM patients these values are reduced ${ }^{49}$. The effect of endurance training on ventricular deformation, torsion and untwisting rate needs further investigation, but promising findings report exercise-induced supranormal LV untwisting rates ${ }^{50}$, confirming again the physiological LV response to exercise.

Finally, parallel to the improvement in echocardiographic techniques and image resolution, a surprising high prevalence of $\mathrm{LV}$ 


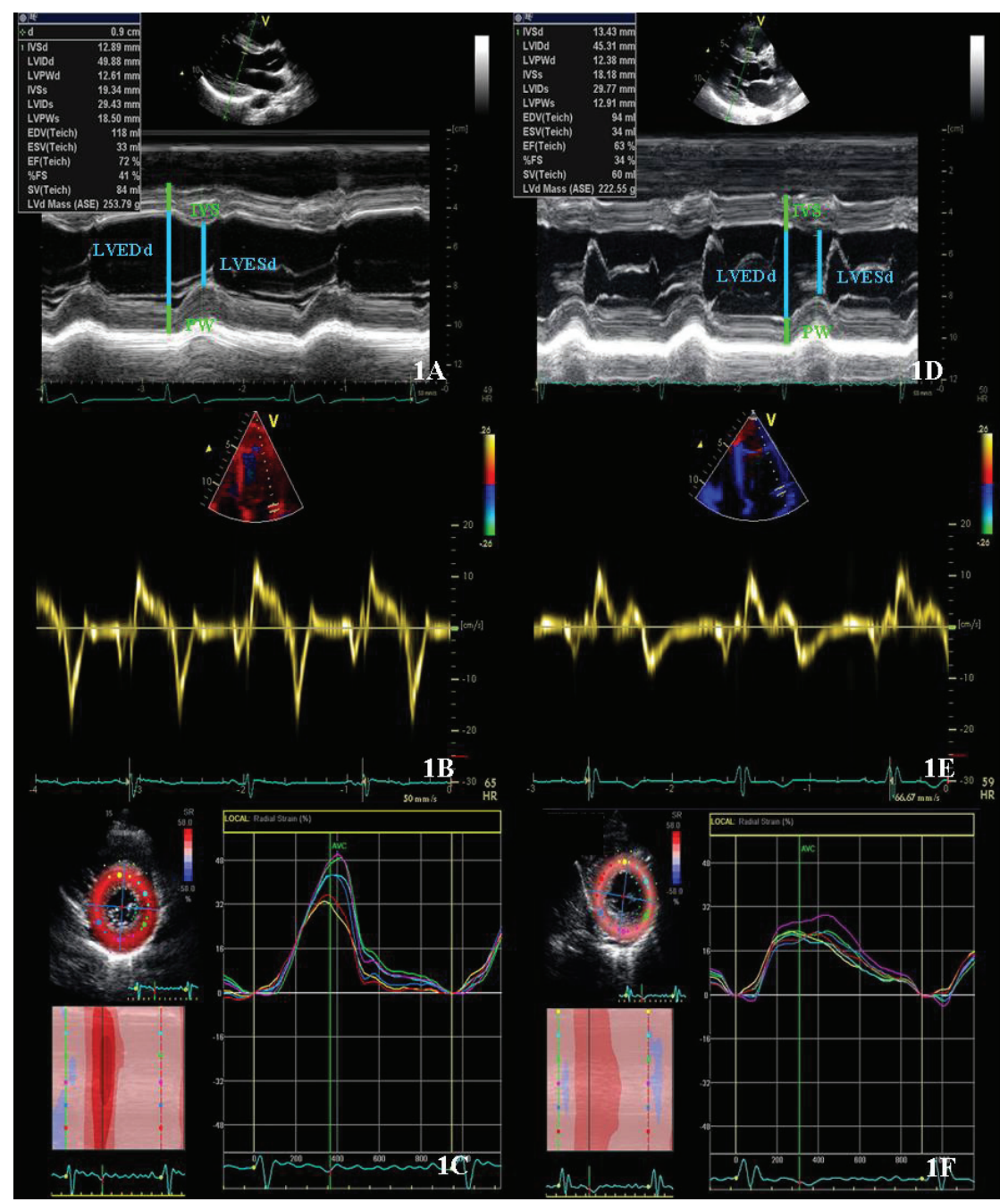

Figure 1. Echocardiographic assessment of an athlete with left ventricular hypertrophic adaptation (Figure 1: A, B, C) and a patient with a mild form of hypertrophic cardiomyopathy (Figure 1: D, E, F). Patients with hypertrophic cardiomyopathy present smaller LV enddiastolic diameters, reduced radial strain values and reduced velocities of the mitral annulus as compared to athletes.

hypertrabeculation has been described in athletes. Gati et al. ${ }^{51}$ in a cohort of 1146 athletes studied by echocardiography, reported trabeculations in $20 \%$ of the athletes, and even more, around $8 \%$ fulfilled conventional criteria for the diagnosis of LV non-compaction cardiomyopathy; this prevalence raised to $13 \%$ when only black athletes were considered. LV non-compaction cardiomyopathy is a rare cardiomyopathy thought to be secondary to the arrest of normal myocardial development, resulting in multiple deep ventricular trabeculations ${ }^{52}$. This entity has a wide clinical expression from asymptomatic patients to advanced cases with three characteristic symptoms: heart failure, thromboembolic events and fatal arrhythmias $^{53}$, and has indeed been related to exercise-related SCD in young athletes ${ }^{54}$. The mechanisms implicated in LV hypertrabeculation in athletes are still unknown, but the reported high prevalence suggests that it might be another expression of cardiac adaptation to increased preload and afterload influenced by genetic and ethnical factors ${ }^{51}$. Structural echocardiographic features that could help to differentiate cardiac adaptive remodeling from disease are: the location of trabeculations (apical region in LV non-compaction cardiomyopathy versus mid-cavity region in athletes) and the evidence of late enhancement in cardiac MRI following gadolinium in LV non-compaction cardiomyopathy ${ }^{54}$. Furthermore, LV noncompaction cardiomyopathy patients may have reduced systolic and diastolic function while athletes with LV hypertrabeculation normally have no systolic or diastolic dysfunction. In the few cases with slightly low LV ejection fraction, a normal or even supranormal increase in LV systolic function with exercise could help us to distinguish pathology from physiological adaptation ${ }^{51}$.

\section{The right ventricle}

During exercise, both ventricles have to increase stroke volume in response to the increased cardiac output demanded during exercise. This workload imposes high stress to all myocardial structures, which seems to be especially important in the right ventricle (RV) that typically works at low pressures in physiological conditions ${ }^{55}$. Classically, the study of the athlete's heart was focused on the LV; but in the last two decades, with the introduction of advanced echocardiographic techniques and MRI, the RV exercise-remodeling has 
started to be described. Structurally, endurance exercise has been related to RV enlargement, typically balanced with LV dilatation ${ }^{56}$. Functionally, high intensity endurance exercise has been related to lower global RV peak systolic longitudinal strain values at rest as compared to controls; the RV basal is the segment most affected in this change $\mathrm{e}^{57}$. To date, whether these lower strain values are the result of myocardial damage ${ }^{58}$ or are only an adaptive response demonstrated by an increased reserve after exercise provocation ${ }^{59}$ is still controversial. So far, few studies have focused on the RV in strength athletes but such RV remodeling seems to be less pronounced ${ }^{60}$. Extreme RV remodeling cases in elite ultra-endurance athletes may be indistinguishable from arrhythmogenic right ventricular dysplasia (ARVD). ARVD is a desmosomal cardiomyopathy characterized by progressive adipose and fibrosis myocardial infiltration with potential bad prognosis and constitutes one of the most important causes of sudden death in young athletes ${ }^{13}$. Various studies have demonstrated more rapid disease progression in patients that practice moderate-high intensity exercise, making the differential diagnosis between disease and cardiac remodeling even more challenging $^{61}$. As previously mentioned, endurance exercise can induce adaptive physiologic biventricular dilatation, where the ratio of LV/RV remains unchanged. On the other hand, a reduced LV/RV ratio could be a warning sign of underlying disease ${ }^{62}$. In addition, athlete's RV remodeling has proved to be global as opposed to that observed in ARVD patients who show a disproportionate enlargement of the RV outflow tract. Functionally, no motion abnormalities have been described in athletes ${ }^{62}$ despite having a lower deformation in the basal segment of the RV; abnormal motion of the RV is essential data to fulfil the ARVD diagnostic criteria ${ }^{63}$. Figure 2 illustrates this echocardiographic differential diagnosis. Finally in doubtful cases, MRI can provide us an accurate structural and functional RV evaluation, distinguishing segments with dyskinesia, fibrosis or outflow tract microaneurysms ${ }^{64}$. However, to date, there is no single sign available to differentiate both entities and consequently, a combination of clinical and family history, electrocardiographic and echocardiographic features are recommended. Table 4 summarizes the main echocardiographic features used to differentiate athlete's heart from early stages of myocardial disease.

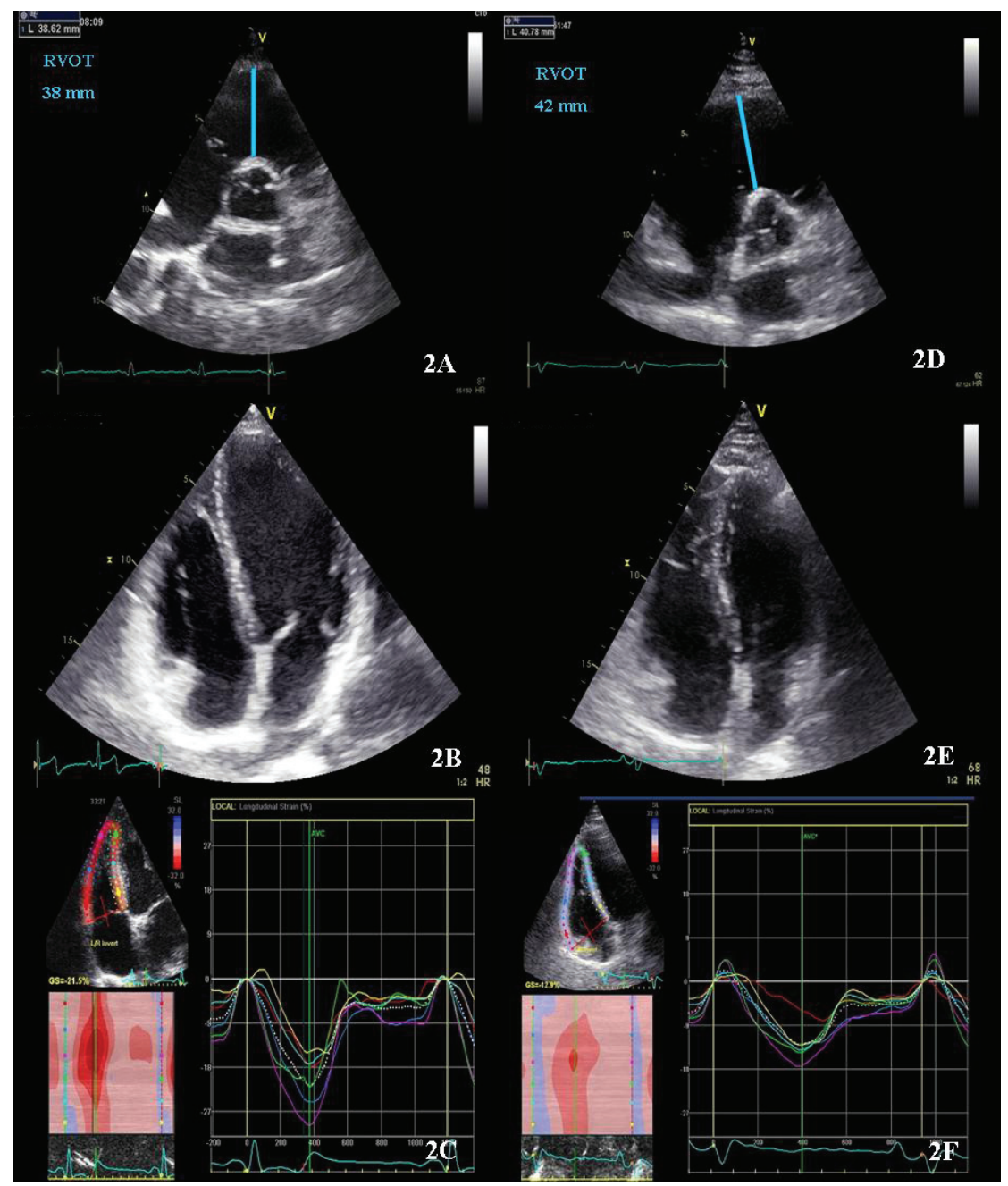

Figure 2. Echocardiographic assessment of an athlete with right ventricle remodelling (Figure 2: A, B, C); and a patient with arrhythmogenic right ventricular dysplasia in early stage (Figure 2: D, E, F). Patients with arrhythmogenic right ventricular dysplasia in early stage can present only mild RV dilatation but the relationship between LV and RV cavity tend to be less than 1 and the RVOT is at least mildly dilated and they present reduced RV global and segmental strain values as compared to athletes. 
Table 4. Echocardiographic features to differentiate athlete's heart from cardiomyopathies. LV GLS: Left ventricle Global Longitudinal Strain.

\begin{tabular}{|c|c|c|}
\hline & $\begin{array}{c}\text { Hypertrophy } \\
\text { cardiomyopathy }\end{array}$ & Athlete's heart \\
\hline $\begin{array}{l}\text { LV end-diastolic } \\
\text { diameter }\end{array}$ & $\leq 45 \mathrm{~mm}$ & $>54 \mathrm{~mm}$ \\
\hline LV volume/LV mass & Reduced & Normal \\
\hline E' mitral lateral annulus & Reduced & Normal or supranormal \\
\hline \multirow[t]{2}{*}{$\begin{array}{l}\text { LV radial and } \\
\text { circumferential Strain }\end{array}$} & Decreased & Normal or supranormal \\
\hline & $\begin{array}{l}\text { LV non compaction } \\
\text { cardiomiopathy }\end{array}$ & Athlete's heart \\
\hline Trabeculation location & Apical & Mid-cavity \\
\hline E'mitral lateral annulus & Normal or reduced & Normal or supranormal \\
\hline \multirow[t]{2}{*}{$\begin{array}{l}\text { LV GLS at rest } \\
\text { LV GLS during effort }\end{array}$} & $\begin{array}{l}\text { Normal or reduced } \\
\text { Reduced }\end{array}$ & $\begin{array}{c}\text { Normal or slightly reduced } \\
\text { Normal or supranormal }\end{array}$ \\
\hline & $\begin{array}{l}\text { Arrhythmogenic right } \\
\text { ventricular dysplasia }\end{array}$ & Athlete's heart \\
\hline RV enlargement & Early RVOT dilatation & Global \\
\hline Motion abnormalities & Yes & No \\
\hline Ratio RV/LV volumes & $\geq 1$ & $<1$ \\
\hline
\end{tabular}

\section{Conclusions}

In summary, echocardiography is a useful imaging tool to detect underlying heart disease that may imply a risk for people practicing sport and at the same time is a non-expensive and non-invasive technique to evaluate cardiac adaptation to training. The challenge remains the diagnosis and differentiation of extreme adaptation to training that very much resembles early stages of some myocardial diseases. Recently developed tools to better quantify cardiac performance have improved this issue but still more knowledge on the pathophysiology of cardiac adaptation to training is needed to optimize the identification of subjects at risk for sudden death or irreversible cardiac damage.

\section{Author contributions}

Gonzalo Grazioli: reviewed the literature, prepared tables wrote the manuscript.

Maria Sanz: reviewed the literature, prepared tables wrote the manuscript.

Silvia Montserrat: reviewed the literature and critically revised the manuscript at all stages.
Bàrbara Vidal: reviewed the literature and critically revised the manuscript at all stages.

Marta Sitges: coordinated and critically revised the manuscript at all stages.

All authors revised the manuscript and agreed to the final content.

\section{Competing interests}

No competing interests were disclosed.

\section{Grant information}

This work was partially funded by grants from Generalitat de Catalunya (FI-AGAUR 2014-2017 (RH 040991, M. Sanz) and Consell Catala de l'Esport 11/2014, and from the Spanish Government (Plan Nacional I+D+i, Ministerio de Innovación y Ciencia DEP 2010-20565, Intensificación Actividad Investigadora, Instituto de Salud Carlos III (M Sitges), Plan Nacional I+D, Ministerio de Economia y Competitividad DEP2013-44923-P).

\section{Acknowledgements}

To the Mémora Group for supporting research into the prevention of sport-related sudden death. 
1. O'Keefe JH, Schnohr P, Lavie CJ: The dose of running that best confers longevity. Heart. 2013; 99(8): 588-591.

PubMed Abstract | Publisher Full Text

2. Lee $\mathrm{DC}$, Pate RR, Lavie $\mathrm{CJ}$, et al.: Leisure-time running reduces all-cause and cardiovascular mortality risk. J Am Coll Cardiol. 2014; 64(5): 472-81. PubMed Abstract | Publisher Full Text | Free Full Text

3. Kim JH, Malhotra R, Chiampas G, et al:: Cardiac arrest during long-distance running races. N Engl J Med. 2012; 366(2): 130-40. PubMed Abstract | Publisher Full Text

4. Marijon E, Tafflet M, Celermajer DS, et al.: Sports-related sudden death in the general population. Circulation. 2011; 124(6): 672-81.

PubMed Abstract | Publisher Full Text

5. Corrado D, Pelliccia A, Bjørnstad HH, et al:: Cardiovascular pre-participation screening of young competitive athletes for prevention of sudden death: proposal for a common European protocol. Consensus Statement of the Study Group of Sport Cardiology of the Working Group of Cardiac Rehabilitation and Exercise Physiology and the Working Group of Myocardial and Pericardial Diseases of the European Society of Cardiology. Eur Heart J. 2005; 26(5): 516-24.

PubMed Abstract | Publisher Full Text

6. Perez M, Fonda $\mathrm{H}$, Le VV, et al.: Adding an electrocardiogram to the preparticipation examination in competitive athletes: a Systematic Review. Curr Probl Cardiol. 2009; 34(12): 586-662.

PubMed Abstract | Publisher Full Text

7. Wheeler MT, Heidenreich PA, Froelicher VF, et al: Cost-effectiveness of preparticipation screening for prevention of sudden cardiac death in young athletes. An Intenal Med. 2010; 152(5): 276-286.

PubMed Abstract | Publisher Full Text | Free Full Text

8. Rizzo M, Spataro A, Cecchetelli C, et al:: Structural cardiac disease diagnosed by echocardiography in asymptomatic young male soccer players: implications for pre-participation screening. Br J Sports Med. 2012; 46(5): 371-3.

PubMed Abstract | Publisher Full Text

9. Grazioli G, Merino B, Montserrat S, et al:: Usefulness of echocardiography in preparticipation screening of competitive athletes. Rev Esp Cardiol (Engl Ed). 2014; 67(9): 701-705

PubMed Abstract | Publisher Full Text

10. Wyman RA, Chiu RY, Rahko PS: The 5-minute screening echocardiogram for athletes. J Am Soc Echocardiogr. 2008; 21(7): 786-8.

PubMed Abstract | Publisher Full Text

11. Weiner RB, Wang F, Hutter AM Jr, et al.: The feasibility, diagnostic yield, and learning curve of portable echocardiography for out-of-hospital cardiovascular disease screening. J Am Soc Echocardiogr. 2012; 25(5): 568-75. PubMed Abstract | Publisher Full Text

12. Evangelista A, Flachskampf F, Lancellotti $P$, et al:: European Association of Echocardiography recommendations for standardization of performance, digital storage and reporting of echocardiographic studies. Eur J Echocardiogr. 2008; 9(4): 438-48.

PubMed Abstract | Publisher Full Text

13. Maron BJ, Doerer JJ, Haas TS, et al:: Sudden deaths in young competitive athletes: analysis of 1866 deaths in the United States, 1980-2006. Circulation. 2009; 119(8): 1085-92.

PubMed Abstract | Publisher Full Text

14. Gersh BJ, Maron BJ, Bonow RO, et al:: 2011 ACCF/AHA Guideline for the Diagnosis and Treatment of Hypertrophic Cardiomyopathy: a report of the American College of Cardiology Foundation/American Heart Association Task Force on Practice Guidelines. Developed in collaboration with the American Association for Thoracic Surgery, American Society of Echocardiography, American Society of Nuclear Cardiology, Heart Failure Society of America, Heart Rhythm Society, Society for Cardiovascular Angiography and Interventions, and Society of Thoracic Surgeons. J Am Coll Cardiol. 2011; 58(25): e212-60.

PubMed Abstract | Publisher Full Text

15. Rowin EJ, Maron BJ, Appelbaum E, et al.: Significance of false negative electrocardiograms in preparticipation screening of athletes for hypertrophic cardiomyopathy. Am J Cardiol. 2012; 110(7): 1027-1032. PubMed Abstract | Publisher Full Text

16. Elliott PM, Anastasaki SA, Borger MA, et al:: 2014 ESC Guidelines on diagnosis and management of hypertrophic cardiomyopathy: the Task Force for the Diagnosis and Management of Hypertrophic Cardiomyopathy of the European Society of Cardiology (ESC). Eur Heart J. 2014; 35(39): 2733-79. PubMed Abstract | Publisher Full Text

17. Fuller CM, McNulty CM, Spring D a, et al:: Prospective screening of 5,615 high school athletes for risk of sudden cardiac death. Med Sci Sports Exerc. 1997; 29(9): 1131-1138.

PubMed Abstract | Publisher Full Text

18. Lytrivi ID, Wong $\mathrm{AH}, \mathrm{Ko} \mathrm{HH}$, et al.: Echocardiographic diagnosis of clinically silent congenital coronary artery anomalies. Int J Cardiol. 2008; 126(3): 386-393.

PubMed Abstract | Publisher Full Text

19. Pelliccia A, Di Paolo FM, De Blasiis E, et al.: Prevalence and clinical significance of aortic root dilation in highly trained competitive athletes. Circulation. 2010 122(7): 698-706.

PubMed Abstract | Publisher Full Text

20. Stefani L, De Luca A, Maffulli N, et al.: Speckle tracking for left ventricle performance in young athletes with bicuspid aortic valve and mild aortic regurgitation. Eur J Echocardiogr. 2009; 10(4): 527-31.

PubMed Abstract | Publisher Full Text

21. Budts W, Börjesson M, Chessa M, et al.: Physical activity in adolescents and adults with congenital heart defects: individualized exercise prescription. Eur Heart J. 2013; 34(47): 3669-74.

PubMed Abstract | Publisher Full Text

22. Corrado D, Basso C, Pavei A, et al.: Trends in sudden cardiovascular death in young competitive athletes after implementation of a preparticipation screening program. JAMA. 2006; 296(13): 1593-1601.

PubMed Abstract | Publisher Full Text

23. Steinvil A, Chundadze T, Zeltser D, et al:: Mandatory electrocardiographic screening of athletes to reduce their risk for sudden death proven fact or wishful thinking? J Am Coll Cardiol. 2011; 57(11): 1291-6. PubMed Abstract | Publisher Full Text

24. Menafoglio A, Di Valentino M, Segatto JM, et al: Costs and yield of a 15-month preparticipation cardiovascular examination with ECG in 1070 young athletes in Switzerland: implications for routine ECG screening. Br J Sports Med. 2014; 48(15): 1157-61.

PubMed Abstract | Publisher Full Text

25. Maron BJ, Haas TS, Ahluwalia A, et al.: Incidence of cardiovascular sudden deaths in Minnesota high school athletes. Heart Rhythm. 2013; 10(3): 374-7. PubMed Abstract | Publisher Full Text

26. La Gerche A, Baggish AL, Knuuti J, et al:: Cardiac imaging and stress testing asymptomatic athletes to identify those at risk of sudden cardiac death. JACC Cardiovasc Imaging. 2013; 6(9): 993-1007.

PubMed Abstract | Publisher Full Text

27. Maron BJ, Friedman RA, Kligfield P, et al:: Assessment of the 12-Lead ECG as a Screening test for detection of cardiovascular disease in healthy general populations of young People (12-25 Years of Age): a Scientific Statement From the American Heart Association and the American College of Cardiology. Circulation. 2014; 130(15): 1303-34. PubMed Abstract | Publisher Full Text

28. Ljungqvist $\mathrm{A}$, Jenoure $\mathrm{P}$, Engebretsen $\mathrm{L}$, et al:: The International Olympic Committee (IOC) Consensus Statement on periodic health evaluation of elite athletes March 2009. Br J Sports Med. 2009; 43(9): 631-643. PubMed Abstract | Publisher Full Text

29. Dvorak J, Kramer EB, Schmied CM, et al.: The FIFA medical emergency bag and FIFA 11 steps to prevent sudden cardiac death: setting a global standard and promoting consistent football field emergency care. Br J Sports Med. 2013; 47(18): 1199-202 PubMed Abstract | Publisher Full Text

30. Fuller CM: Cost effectiveness analysis of screening of high school athletes for risk of sudden cardiac death. Med Sci Sports Exerc. 2000; 32(5): 887-90. PubMed Abstract

31. Koch S, Cassel M, Linne K, et al.: ECG and echocardiographic findings in 10-15year-old elite athletes. Eur J Prev Cardiol. 2014; 21(6): 774-781.

PubMed Abstract | Publisher Full Text

32. Sitges M, Gutiérrez JA, Brugada J, et al:: Consensus for the prevention of sudden cardiac death in athletes. Apunt Med Esport. 2013; 48(177): 35-41. Reference Source

33. Utomi V, Oxborough D, Whyte GP, et al:: Systematic review and meta-analysis of training mode, imaging modality and body size influences on the morphology and function of the male athlete's heart. Heart. 2013; 99(23): 1727-33. PubMed Abstract | Publisher Full Text

34. Henschen S: Skidlauf und Skidwettlauf. Eine medizinische Sportstudie. Mitt Med Klin Upsala Jena. 1899; 2: 15-18.

35. Hunt EA: Electrocardiographic study of $\mathbf{2 0}$ champion swimmers before and after 110-yard sprint swimming competition. Can Med Assoc J. 1963; 88: 12511253.

PubMed Abstract | Free Full Text

36. Van Ganse W, Versee L, Eylenbosch W, et al:: The electrocardiogram of athletes. Comparison with untrained subjects. Br Heart J. 1970; 32(2): 160-164. PubMed Abstract | Publisher Full Text | Free Full Text

37. Morganroth J, Maron BJ, Henry WL, et al:: Comparative left ventricular dimensions in trained athletes. Ann Intern Med. 1975; 82(4): 521-524. PubMed Abstract | Publisher Full Text

38. Pluim BM, Zwinderman AH, van der Laarse A, et al.: The athlete's heart. A metaanalysis of cardiac structure and function. Circulation. 2000; 101(3): 336-344. PubMed Abstract | Publisher Full Text

39. Pelliccia A, Maron BJ, Spataro A, et al:: The upper limit of physiologic cardiac hypertrophy in highly trained elite athletes. N Engl J Med. 1991; 324(5): 295-301.

PubMed Abstract | Publisher Full Text

40. Sharma S, Maron BJ, Whyte G, et al:: Physiologic limits of left ventricular hypertrophy in elite junior athletes: relevance to differential diagnosis of 
athlete's heart and hypertrophic cardiomyopathy. J Am Coll Cardiol. 2002; 40(8): 1431-1436.

PubMed Abstract | Publisher Full Text

41. Caselli S, Maron MS, Urbano-Moral JA, et al.: Differentiating left ventricular hypertrophy in athletes from that in patients with hypertrophic cardiomyopathy. Am J Cardiol. 2014; 114(9): 1383-9. PubMed Abstract | Publisher Full Text

42. Luijkx T, Cramer MJ, Buckens CF, et al:: Unravelling the grey zone: cardiac MRI volume to wall mass ratio to differentiate hypertrophic cardiomyopathy and the athlete's heart. Br J Sports Med. 2013; 992: 1-7. PubMed Abstract | Publisher Full Text

43. Pelà G, Bruschi G, Montagna L, et al:: Left and right ventricular adaptation assessed by Doppler tissue echocardiography in athletes. J Am Soc Echocardiogr. 2004; 17(3): 205-211. PubMed Abstract | Publisher Full Text

44. Matsumura Y, Elliott PM, Virdee MS, et al: Left ventricular diastolic function assessed using Doppler tissue imaging in patients with hypertrophic cardiomyopathy: relation to symptoms and exercise capacity. Heart. 2002; 87(3): 247-251.

PubMed Abstract | Publisher Full Text | Free Full Text

45. Pelliccia A, Culasso F, Di Paolo FM, et al.: Physiologic left ventricular cavity dilatation in elite athletes. Ann Intern Med. 1999; 130(1): 23-31. PubMed Abstract | Publisher Full Text

46. Gilbert CA, Nutter DO, Felner JM, et al:: Echocardiographic study of cardiac dimensions and function in the endurance-trained athlete. Am J Cardiol. 1977; 40(4): 528-533.

PubMed Abstract | Publisher Full Text

47. Abergel E, Chatellier G, Hagege AA, et al.: Serial left ventricular adaptations in world-class professional cyclists: Implications for disease screening and follow-up. J Am Coll Cardiol. 2004; 44(1): 144-149. PubMed Abstract | Publisher Full Text

48. Baggish AL, Yared K, Wang F, et al.: The impact of endurance exercise training on left ventricular systolic mechanics. Am J Physiol Hear Circ Physiol. 2008; 295(3): H1109-H1116. PubMed Abstract | Publisher Full Text

49. Lakdawala NK, Thune JJ, Colan SD, et al:: Subtle abnormalities in contractile function are an early manifestation of sarcomere mutations in dilated cardiomyopathy. Circ Cardiovasc Genet. 2012; 5(5): 503-510. PubMed Abstract | Publisher Full Text | Free Full Text

50. Notomi Y, Martin-Miklovic MG, Oryszak SJ, et al.: Enhanced ventricular untwisting during exercise: a mechanistic manifestation of elastic recoil described by doppler tissue imaging. Circulation. 2006; 113(21): 2524-2533. PubMed Abstract | Publisher Full Text

51. Gati S, Chandra N, Bennett RL, et al.: Increased left ventricular trabeculation in highly trained athletes: do we need more stringent criteria for the diagnosis of left ventricular non-compaction in athletes? Heart. 2013; 99(6): 401-8. PubMed Abstract | Publisher Full Text

52. Paterick TE, Tajik AJ: Left ventricular noncompaction: a diagnostically challenging cardiomyopathy. Circ J. 2012; 76(7): 1556-62. PubMed Abstract | Publisher Full Text

53. Chin TK, Perloff JK, Williams RG, et al:: Isolated noncompaction of left ventricular myocardium. A study of eight cases. Circulation. 1990; 82(2): 507-513.

PubMed Abstract | Publisher Full Text

54. Wan J, Zhao S, Cheng $\mathrm{H}$, et al:: Varied distributions of late gadolinium enhancement found among patients meeting cardiovascular magnetic resonance criteria for isolated left ventricular non-compaction. J Cardiovasc Magn Reson. 2013; 15(1): 20.

PubMed Abstract | Publisher Full Text | Free Full Text

55. La Gerche A, Heidbüchel H, Burns AT, et al:: Disproportionate exercise load and remodeling of the athlete's right ventricle. Med Sci Sports Exerc. 2011; 43(6) 974-81.

PubMed Abstract | Publisher Full Text

56. Scharf M, Brem MH, Wilhelm M, et al:: Cardiac magnetic resonance assessment of left and right ventricular morphologic and functional adaptations in professional soccer players. Am Heart J. 2010; 159(5): 911-918. PubMed Abstract | Publisher Full Text

57. Teske AJ, Prakken NH, De Boeck BW, et al.: Echocardiographic tissue deformation imaging of right ventricular systolic function in endurance athletes. Eur Heart J. 2009; 30(8): 969-77. PubMed Abstract | Publisher Full Text

58. Heidbüchel $\mathrm{H}$, Hoogsteen J, Fagard R, et al:: High prevalence of right ventricular involvement in endurance athletes with ventricular arrhythmias. Role of an electrophysiologic study in risk stratification. Eur Heart J. 2003; 24(16): 1473-1480.

PubMed Abstract | Publisher Full Text

59. La Gerche A, Burns A, D'Hooge J, et al.: Exercise Strain Rate Imaging Demonstrates Normal Right Ventricular Contractile Reserve and Clarifies Ambiguous Resting Measures in Endurance Athletes. J Am Soc Echocardiogr. 2012; 25(3): 253-62.

PubMed Abstract | Publisher Full Text

60. Pagourelias ED, Kouidi E, Efthimiadis GK, et al:: Right atrial and ventricular adaptations to training in male Caucasian athletes: an echocardiographic study. J Am Soc Echocardiogr. 2013; 26(11): 1344-1352.

PubMed Abstract | Publisher Full Text

61. Dewilde W, Boersma L, Delanote J, et al.: Symptomatic arrhythmogenic righ ventricular dysplasia/cardiomyopathy. A two-centre retrospective study of 15 symptomatic ARVD/C cases and focus on the diagnostic value of MRI in symptomatic ARVD/C patients. Acta Cardiol. 2008; 63(2): 181-189. PubMed Abstract | Publisher Full Text

62. Bauce B, Frigo G, Benini G, et al:: Differences and similarities between arrhythmogenic right ventricular cardiomyopathy and athlete's heart adaptations. Br J Sports Med. 2010; 44(2): 148-154.

PubMed Abstract | Publisher Full Text

63. Marcus FI, McKenna WJ, Sherrill D, et al:: Diagnosis of arrhythmogenic right ventricular cardiomyopathy/dysplasia: proposed modification of the Task Force Criteria. Eur Heart J. 2010; 31(7): 806-814. PubMed Abstract | Publisher Full Text | Free Full Text

64. te Riele AS, Tandri H, Bluemke DA: Arrhythmogenic right ventricular cardiomyopathy (ARVC): cardiovascular magnetic resonance update. J Cardiovasc Magn Reson. 2014;16: 50.

PubMed Abstract | Publisher Full Text | Free Full Text 


\section{Open Peer Review}

\section{Current Peer Review Status:}

\section{Version 1}

Reviewer Report 27 July 2015

https://doi.org/10.5256/f1000research.7082.r9498

(C) 2015 Leischik R. This is an open access peer review report distributed under the terms of the Creative Commons Attribution License, which permits unrestricted use, distribution, and reproduction in any medium, provided the original work is properly cited.

\section{Roman Leischik}

Faculty of Health, School of Medicine, University Witten/Herdecke, Witten, Germany

Echocardiography is an informative method for examination of cardiac structures and not dispensable in examination of athletes. Dr Grazioli focused his paper on analysis of left and right ventricle and did it well. Right and left atrial dimensions ${ }^{1-3}$ (and function ${ }^{3,4}$ ), aortic dimension ${ }^{5,6}$ (and stiffness ${ }^{5,7}$ ) or pulmonary dimensions and function ${ }^{8}$ were not focused in this initial article of the sports cardiology channel because it is problematic to start with and to write a complete update with the burden of complete echocardiographic potential/possibilities. In one of his own papers he described alterations of aortic valve/pulmonary valve/mitral valve in athletes and aortic root dilatation or severe pulmonary stenosis ${ }^{9}$.

Echocardiography was recommended for screening of athletes under different circumstances ${ }^{10,13}$ and particularly for follow up ${ }^{14,15}$ examinations. The possibilities of strain echocardiography were discussed in the past ${ }^{16,17}$ and we look forward to new. The global longitudinal strain has better reproducibility ${ }^{18}$, the potential of radial strain seems to be limited in examination of training effects ${ }^{19}$.

I recommend indexing of this article with the option to write an update with further possibilities and importance of echocardiography in the examinations of atrial function/valve and aortic function including 3D echocardiography and the further analysis of recreational athletes ${ }^{20}$ and importance of follow-up examinations ${ }^{21,22}$. The advantage of this sports cardiology channel is the possibility for updating papers with new literature and information and to actualize the growing knowledge in sports cardiology.

\section{References}

1. D'Andrea A, De Corato G, Scarafile R, Romano S, et al.: Left atrial myocardial function in either physiological or pathological left ventricular hypertrophy: a two-dimensional speckle strain study. BrJ Sports Med. 2008; 42 (8): 696-702 PubMed Abstract | Publisher Full Text | Reference Source 2. D'Andrea A, Riegler L, Cocchia R, Scarafile R, et al.: Left atrial volume index in highly trained 
athletes. Am Heart J. 2010; 159 (6): 1155-1161 PubMed Abstract | Publisher Full Text | Reference Source

3. D'Ascenzi F, Pelliccia A, Natali BM, Zacà V, et al.: Morphological and Functional Adaptation of Left and Right Atria Induced by Training in Highly Trained Female Athletes. Circ Cardiovasc Imaging. 2014; 7 (2): 222-229 PubMed Abstract | Publisher Full Text | Reference Source

4. Leischik R, Littwitz H, Dworrak B, Garg P, et al.: Evaluation of Left Atrial Mechanics: Function, History, Novel Techniques, Advantages, and Pitfalls. Biomed Res Int. 2015; 2015. Publisher Full Text | Reference Source

5. D'Andrea A, Cocchia R, Riegler L, Salerno G, et al.: Aortic stiffness and distensibility in top-level athletes. J Am Soc Echocardiogr. 2012; 25 (5): 561-567 PubMed Abstract | Publisher Full Text | Reference Source

6. D'Andrea A, Cocchia R, Riegler L, Scarafile R, et al.: Aortic root dimensions in elite athletes. Am J Cardiol. 2010; 105 (11): 1629-1634 PubMed Abstract | Publisher Full Text | Reference Source 7. Nistri S, Grande-Allen J, Noale M, Basso C, et al.: Aortic elasticity and size in bicuspid aortic valve syndrome. Eur Heart J. 2008; 29 (4): 472-479 PubMed Abstract | Publisher Full Text | Reference Source

8. Bossone $\mathrm{E}$, D'Andrea A, D'Alto M, Citro R, et al.: Echocardiography in pulmonary arterial hypertension: from diagnosis to prognosis. J Am Soc Echocardiogr. 2013; 26 (1): 1-14 PubMed Abstract | Publisher Full Text | Reference Source

9. Grazioli G, Merino B, Montserrat S, Vidal B, et al.: Usefulness of Echocardiography in Preparticipation Screening of Competitive Athletes. Rev Esp Cardiol (Engl Ed). 2014; 67 (9): 701-715 PubMed Abstract | Publisher Full Text | Reference Source

10. Yim ES: Aortic root disease in athletes: aortic root dilation, anomalous coronary artery, bicuspid aortic valve, and Marfan's syndrome. Sports Med. 2013; 43 (8): 721-732 PubMed Abstract | Publisher Full Text | Reference Source

11. Yim ES, Basilico F, Corrado G: Early screening for cardiovascular abnormalities with preparticipation echocardiography: utility of focused physician-operated echocardiography in preparticipation screening of athletes. J Ultrasound Med. 2014; 33 (2): 307-313 PubMed Abstract | Publisher Full Text | Reference Source

12. Calò L, Sperandii F, Martino A, Guerra E, et al.: Echocardiographic findings in 2261 peripubertal athletes with or without inverted T waves at electrocardiogram. Heart. 2015; 101 (3): 193 200 PubMed Abstract | Publisher Full Text | Reference Source

13. Paterick TE, Gordon T, Spiegel D: Echocardiography: Profiling of the Athlete's Heart. J Am Soc Echocardiogr. 2014; 27 (9): 940-948 PubMed Abstract | Publisher Full Text | Reference Source 14. Leischik R, Dworrak B, Foshag P, Strauss M, et al.: Pre-Participation and Follow-Up Screening of Athletes for Endurance Sport. J Clin Med Res. 2015; 7 (6): 385-392 PubMed Abstract | Free Full Text | Publisher Full Text

15. Leischik R: Endurance Sport and Cardiac Injury. Kardiol Pol. 2014; 72 (7): 587-597 PubMed Abstract | Publisher Full Text | Reference Source

16. D'Andrea A, Cocchia R, Riegler L, Scarafile R, et al.: Left ventricular myocardial velocities and deformation indexes in top-level athletes. J Am Soc Echocardiogr. 2010; 23 (12): 1281-1288 PubMed Abstract | Publisher Full Text | Reference Source

17. Caselli S, Montesanti D, Autore C, Di Paolo FM, et al.: Patterns of left ventricular longitudinal strain and strain rate in Olympic athletes. J Am Soc Echocardiogr. 2015; 28 (2): 245-253 PubMed Abstract | Publisher Full Text | Reference Source

18. Leischik R, Dworrak B, Hensel K: Intraobserver and interobserver reproducibility for radial, circumferential and longitudinal strain echocardiography. Open Cardiovasc Med J. 2014; 8: 102-109 PubMed Abstract | Free Full Text | Publisher Full Text 
19. Vitarelli A, Capotosto L, Placanica G, Caranci F, et al.: Comprehensive assessment of biventricular function and aortic stiffness in athletes with different forms of training by threedimensional echocardiography and strain imaging. Eur Heart J Cardiovasc Imaging. 2013; 14 (10): 1010-1020 PubMed Abstract | Publisher Full Text

20. Leischik R, Spelsberg N: Endurance sport and "cardiac injury": a prospective study of recreational ironman athletes. Int J Environ Res Public Heath. 2014; 11 (9): 9082-9100 PubMed Abstract | Free Full Text | Publisher Full Text | Reference Source

21. Leischik R, Dworrak B: Ugly duckling or Nosferatu? Cardiac injury in endurance sport screening recommendations. Eur Rev Med Pharmacol Sci. 2014; 18 (21): 3274-3290 PubMed Abstract | Reference Source

22. Demirelli S, Sam CT, Ermis E, Degirmenci H, et al.: Long-Term Cardiac Remodeling in Elite Athletes: Assessment by Tissue Doppler and Speckle Tracking Echocardiography. Echocardiography . 2014. PubMed Abstract | Publisher Full Text

Competing Interests: No competing interests were disclosed.

\section{I confirm that I have read this submission and believe that I have an appropriate level of expertise to confirm that it is of an acceptable scientific standard.}

Reviewer Report 20 July 2015

https://doi.org/10.5256/f1000research.7082.r9496

(C) 2015 D'Ascenzi F. This is an open access peer review report distributed under the terms of the Creative Commons Attribution License, which permits unrestricted use, distribution, and reproduction in any medium, provided the original work is properly cited.

\section{Flavio D'Ascenzi}

Department of Medical Biotechnologies, University of Siena, Siena, Italy

The paper by Grazioli and colleagues provides a comprehensive review on the current knowledge and the clinical implications of echocardiography when applied to the evaluation of athlete's heart in the context of pre-participation screening. The paper is currently focused on right and left ventricles, is well written, and analyses not only standard echocardiography, but also the novel echocardiographic techniques applied to athlete's heart, with a specific focus on the differential diagnosis between exercise-induced physiological remodelling and the diseases most commonly cause of sudden cardiac death.

\section{Major revisions}

Although the clinical implications of biatrial analysis has to be understood, in my opinion a brief paragraph on the analysis of biatrial morphology and function could be potentially of interest, also considering the some authors have demonstrated its utility in the differential diagnosis between athlete's heart and cardiomyopathies.

An interesting point of using echocardiography in the context of a screening has not been analysed. Although some authors debate about the utility and the costs of echocardiography, in my opinion the fundamental question of the application of echocardiography to the pre- 
participation screening in athletes is WHEN performing this exam. Considering that a frequent echocardiographic evaluation is not feasible in low-risk populations and dramatically increases the cost in absence of real clinical advantages, one has to suppose that one or two exams can be performed during the career of a non-professional athlete. Although some congenital defects can be detected in the early phase of the life of an individual, some of the most common cause of sudden cardiac death are the genetic myocardial diseases, such as HCM, DCM, and ARVC, all known to have a delayed phenotype expression. Thus, performing an echocardiogram at the beginning of the athletic career of a child could detect congenital defects, but could be misleading in excluding the cardiomyopathies most commonly associated with sudden cardiac death, with a typical expression in the II-III (or even IV) decades of life of a young athlete. I think that the authors should analyse this clinical question and should provide a personal opinion based on the current available evidences and on the experience of their Center.

\section{Minor revisions}

In table 1 I think that "aortic coartation" should be included in the section "suprasternal view".

Table 2: exercise has not proven to be a determinant of a physiological dilation of the aorta; conversely, it has been demonstrated that aortic dimensions are comparable with those of the general population. Accordingly, I suggest removing "mild aortic dilation" from table 2, section "athlete's heart".

Atherosclerotic coronary artery disease cannot be detected by echocardiography, although indirect signs such as left ventricular wall motion abnormalities can suggest its presence. However, considering the signs are uncommonly observed in athletes, I suggest to remove "Atherosclerotic coronary artery disease" from table 2, section "sudden cardiac death".

Left ventricular non compaction: "it might be another expression of cardiac adaptation to increased preload and afterload influenced by genetic and ethnical factor": ref. \#51 is not correct because does refer to an hypothesis rather than an explanation of the phenomenon. I suggest to cite the article by Gati S. et al (Circulation 2014) and the work by D'Ascenzi F. et al (Int J Cardiol 2015) both explaining the physiological determinants of benign hypertrabeculation in the athletes.

Table 3: the definition "competitive athletes, high static and dynamic component endurance training, > 10 hours/week" is not clear: which is the opinion of the authors? Although it is clear that echocardiography is not recommended in subjects engaged in recreational sports, which are the athletes to be evaluated by echocardiography? All the competitive athletes? Athletes with abnormal findings at resting ECG or at history/physical examination? Athletes engaged in highvolume training programs?...Please specify.

Table 4

At the present time, LV circumferential and radial strains cannot be definitively suggested to distinguish between cardiomyopathies and athlete's heart. LV longitudinal strain is highly sensitive for myocardial disorders and more reproducible than circumferential and radial strains ((Feigenbaum H, Circ J 2012). Because of the LV shortens from base to apex in systole, the fixed short-axis tracking that is required for circumferential and radial strain is more difficult than longitudinal tracking. Particularly, radial strain is intrinsically more vulnerable to measurement variability because strain assessed in these orientations represents an aggregate measure of endocardial, mesocardial and epicardial tissue motion, encompassing both myocardial fiber 
shortening and global LV torsion in systole. The best inter- and intra-observed reproducibility is observed for LV longitudinal strain and particularly data based on measurements of LV radial strain should be interpreted with caution (Cheng S, J Am Soc Echocardiogr 2013). A limited reliability has been observed also for LV circumferential strain measurements. A possible explanation is that circumferential deformation twist can hardly be assessed in the same view, because the base descends to the apex. This movement makes the correct measurement in the short axis view impossible in two different time-points or even in two different days.

Finally, LV longitudinal strain measurements are known to be more robust than radial ones (MorAvi, Eur J Echocardiogr 2011). According to these considerations and to the fact that LV longitudinal strain is the only form of strain that is used routinely (Feigenbaum H, Circ J 2012), I suggest to remove both radial and circumferential strains from table 4 and to stress in the text that future studies are needed to evaluate whether these deformation parameters could be used in the clinical practice.

"motion abnormalities" -> please correct with "wall motion abnormalities"

Table 4: according to the current available data on deformation analysis applied to the athlete's heart, I suggest to describe LV GLS at rest as "normal" and not "normal or slightly reduced".

Competing Interests: No competing interests were disclosed.

I confirm that I have read this submission and believe that I have an appropriate level of expertise to confirm that it is of an acceptable scientific standard, however I have significant reservations, as outlined above.

Reviewer Report 26 June 2015

https://doi.org/10.5256/f1000research.7082.r9040

(c) 2015 Müssigbrodt A. This is an open access peer review report distributed under the terms of the Creative Commons Attribution License, which permits unrestricted use, distribution, and reproduction in any medium, provided the original work is properly cited.

\section{Andreas Müssigbrodt}

Department of Electrophysiology, University of Leipzig, Leipzig, Germany

This review summarizes some important aspects of echocardiography as a screening tool for the screening of athletes and should therefore be of interest for sports physicians and cardiologists. The potential advantages of this method and the technical aspects are well described.

I would nevertheless recommend to mention potential problems too, mainly overdiagnosis and misdiagnosis with important consequences for the career of athletes and additional costs. In order to prevent overdiagnosis and misdiagnosis, intensive training of sports cardiologists seems to be of utmost importance.

Furthermore, as research in this area often focuses on young, competitive athletes, I would recommend to discuss the potential value of echocardiography for older, non-competitive, 
recreational athletes.

I recommend indexing after minor revision.

Competing Interests: No competing interests were disclosed.

I confirm that I have read this submission and believe that I have an appropriate level of expertise to confirm that it is of an acceptable scientific standard.

The benefits of publishing with F1000Research:

- Your article is published within days, with no editorial bias

- You can publish traditional articles, null/negative results, case reports, data notes and more

- The peer review process is transparent and collaborative

- Your article is indexed in PubMed after passing peer review

- Dedicated customer support at every stage

For pre-submission enquiries, contact research@f1000.com 